\title{
EDUCATIONAL
} TECHNOLOGY

\section{The effectiveness of using instructional objectives with less able secondary school pupils}

\author{
Teo Boon Guat \\ George P. L. Teh \\ Institute of Education, Singapore
}

\begin{abstract}
This study examines the effects of providing less able lower secondary geography pupils with written instructional objectives prior to instruction. Since 1983, teachers in Singapore schools have been writing instructional objectives to guide themselves in their teaching. This study goes one step further to try to answer the question To utilise fully the instructional objectives which teachers have written, can they make use of them to help pupils improve their learning? This study specifically addresses the Normal stream pupils who are academically less able and who require the most guidance and assistance. The results indicated that (i) the use of instructional objectives as an instructional strategy does seem to enhance learning for less able secondary school pupils, (ii) when presented with instructional objectives as an aid to learning, boys appear to benefit more than girls. The implications of these findings are discussed.
\end{abstract}

Numerous studies have been conducted to determine the effectiveness of giving students instructional objectives to assist them in learning. Results have been conflicting due to the many different conditions under which studies have been undertaken. However a recent meta-analysis carried out by Ascencio (1984) statistically supported the use of instructional objectives. When students were grouped by ability, the findings were more favourable.

In six studies which related effectiveness of the use of instructional objectives to learning, three studies (Smith, 1967; Bryant, 1970; Stalians, 1978) revealed no significant results of the effectiveness of instructional objectives on lower ability students, while three other studies (Doty, 1968; Wingard, 1976; Hunter 1987) showed that over ability students have benefited most from the use of instructional objectives. 
A substantial number of empirical studies lend support to the claim that providing students with instructional objectives enhances relevant learning. A number of studies, on the other hand, have recorded experiments in which the availability of instructional objectives did not help relevant learning. However, in none of these instances was relevant learning depressed (Melton, 1978). It is clear then, that instructional objectives can enhance learning under certain conditions.

\section{Methodology}

The sample for this case study comprised 240 pupils from six Secondary One Normal-course classes. The six classes were from three randomly selected schools. Of the two classes in each school, one class was randomly assigned as the treatment class and the other, the control class. The two classes in each school were taught by the same teacher.

The experimental design used for this study was the pretest-posttest control group design (Campbell and Stanley, 1963):

\begin{tabular}{|c|c|c|}
\hline $\begin{array}{l}\text { Experimental } \\
\text { (Pupils provided with objectives) }\end{array}$ & $\mathrm{R}$ & 01 \\
\hline $\begin{array}{l}\text { Control } \\
\text { (Pupils not provided with objectives) }\end{array}$ & $\mathrm{R}$ & 03 \\
\hline
\end{tabular}

The experiment was based on three topics on the geography of Singapore in the Secondary One Normal-course geography syllabus. The three topics were: The Central Business District, Urban Renewal and the Industrial Landscape. The following steps were taken in carrying out the experiment:

i. A week prior to the experiment, the researcher met separately with the three teachers from the three schools who would be teaching an experimental and a control class each.

ii. Before proceeding with the actual experiment, the objective-referenced measure which consisted of fifty multiple-choice items and which served as the pretest as well as the posttest, was administered to all the six classes to establish their entry behaviour for the topics to be taught.

ii. In the experimental classes, before instruction began, the teachers provided each pupil with a list of instructional objectives for the particular topic to be taught. The teachers read aloud the objectives relevant to the lesson at the start of the lesson, after which they 
proceeded with the lesson. The pupils were told to have in hand the list of objectives pertaining to the topic they were studying during lesson time. This was to help guide them during instruction. they were at the same time informed that the objectives would help them study for the test at the end of the three topics.

iv. In the control classes, the same teachers taught as similar lessons as possible to the experimental classes except that no instructional objectives were given to the pupils. The control pupils were also aware that they would be tested at the end of the three topics.

v. The experiment was carried out over a period of four and a half weeks. Nine lessons on the three topics were studied as usually Secondary One pupils study two periods of geography each week.

vi After four and a half weeks of experimentation, the objectivereferenced measure which served as the pretest was administered as the posttest to determine the effects of the treatment.

vii. Classroom observation was carried out at random by the researcher during the period of experimentation to monitor the adherence to procedures in both the experimental and control classes.

\section{Analysis of data}

The statistical analyses of data were based on the posttest scores from the six classes, with the pretest scores as covariate to adjust for initial differences on knowledge of the experimental topics amongst the subjects. Analysis of covariance (ANCOVA) was used to determine any statistical differences between the performance of the three classes exposed to instructional objectives before instruction and the other three classes not exposed to the objectives, and between the performance of boys and girls given objectives. Following the ANCOVA procedures, significant main effects were further analysed by post hoc paired comparisons to examine differences between groups. All null hypotheses were tested at the .05 level of significance.

\section{Results}

The primary purpose of this study was to investigate whether providing less able pupils with instructional objectives to guide them in their learning and informing them of what was expected of them from the lessons, would result in any significant difference in scores on an objective-referenced posttest, compared with pupils who were not given 
such objectives. According to the results of the study, there is a statistically significant difference in posttest scores favouring pupils who were given objectives.

A secondary purpose of this study was to determine whether there was a significant difference in the performance of boys and girls provided with objectives as revealed in the posttest scores. The results indicated that boys provided with instructional objectives achieved significantly higher scores than girls.

The main hypothesis for the study was:

There will be no significant difference in scores on the objectivereferenced posttest between pupils who have been given knowledge of instructional objectives prior to instruction and pupils who do not have prior knowledge of such objectives.

The data applicable to test this hypothesis consisted of the scores from the 50 item posttest. The posttest scores for the two groups of pupils - those presented with objectives and those not presented, were analysed using the ANVOCA procedure with the pretest scores as covariate. Table 1 shows the posttest means of the treatment and control pupils.

Table 1: Posttest means of treatment and control pupils

\begin{tabular}{lccccc} 
& N & $\begin{array}{c}\text { Pretest } \\
\text { Mean }\end{array}$ & Mean & SD & $\begin{array}{c}\text { Adjusted } \\
\text { Mean }\end{array}$ \\
\hline $\begin{array}{l}\text { Treatment (with } \\
\text { objectives) }\end{array}$ & 120 & 12.95 & 32.85 & 6.95 & 32.77 \\
$\begin{array}{l}\text { Control (without } \\
\text { objectives) }\end{array}$ & 120 & 13.49 & 29.10 & 6.16 & 28.98 \\
\hline
\end{tabular}

Table 2: ANCOVA for treatment as main effects with the objective-referenced posttest as the dependent variable adjusted for pretest differences

\begin{tabular}{lccccc} 
Source of Variation & DF & SS & MS & Value & Value \\
\hline $\begin{array}{l}\text { Treatment } \\
\text { (Between groups) }\end{array}$ & 1 & 860.68 & 860.68 & 24.07 & 0.0001 \\
$\begin{array}{l}\text { Error } \\
\text { (Within Groups) }\end{array}$ & 237 & 8476.09 & 35.76 & & \\
Total & 239 & 11338.25 & & & \\
\hline
\end{tabular}


The F statistic of 24.07 shows that a significant difference of beyond the $>.05$ level existed in the posttest scores between the treatment and the control groups. Therefore the main hypothesis may be confidently rejected. Pupils who have been given knowledge of instructional objectives prior to instruction out-performed those without such prior knowledge on the objective-referenced posttest. A secondary hypothesis of the study was:

There will be no significant difference in scores on the objectivereferenced posttest between boys and girls who have been given knowledge of instructional objectives prior to instruction.

For this Hypothesis, the posttest scores of pupils given objectives were subject to an analysis of covariance with sex as the independent variable and the pretest scores as the covariate. The analysis yielded the information in Table 3. Table 4 shows the pretest and posttest means by treatment and sex of pupils.

Table 3: Means of pretest and posttest scores by treatment and sex of pupils

\begin{tabular}{|c|c|c|c|c|c|c|}
\hline & & & Pretest & & & Adjusted \\
\hline & & $\mathrm{N}$ & Mean & Mean & SD & Mean \\
\hline Treatment & Boys & 53 & 14.06 & 34.49 & 6.52 & 34.20 \\
\hline & Girls & 67 & 12.45 & 31.21 & 7.38 & 31.64 \\
\hline Control & Boys & 54 & 14.33 & 29.28 & 6.47 & 28.83 \\
\hline & Girls & 66 & 12.79 & 28.94 & 5.85 & 29.11 \\
\hline
\end{tabular}

Table 4: ANCOVA for treatment boys and girls with the objective-referenced posttest as the dependent variable, adjusted for pretest differences.

\begin{tabular}{lccccc}
$\begin{array}{l}\text { Source of } \\
\text { variation }\end{array}$ & DF & SS & MS & F value & P value \\
\hline $\begin{array}{l}\text { Sex } \\
\text { (Between Groups) }\end{array}$ & 1 & 197.58 & 197.58 & 4.6 & 0.0340 \\
$\begin{array}{l}\text { Error } \\
\text { (Within Groups) }\end{array}$ & 117 & 5021.18 & 42.92 & & \\
\hline
\end{tabular}


The $\mathrm{F}$ value of 4.6 reveals that presented with objectives as aids to learning, boys performed significantly better than girls at the .05 level. This secondary null hypothesis therefore has to be rejected.

\section{Discussion}

From the results obtained there is a need to further discuss two points:

i. The high significant difference between treatment and control groups.

ii. The lowest ability group.

Analysis of covariance indicated that there was an overall high statistical significant difference in posttest means favouring treatment groups, that is, those groups which were given instructional objectives as compared with control groups which were not given instructional objectives. The highly significant difference in mean scores between treatment and control pupils reported in this study is not uncommon in such experiments, as some studies such as those conducted by Khoynejad (1980), Hunter (1982), and Lapolla (1983) have reported significant differences of beyond the .05 level of significance between students aided by instructional objectives and those who were not. Differences of beyond the .01 level are not surprising in this study as the present study tried to heighten the orienting and motivating effects of instructional objectives by avoiding conditions listed out by Melton (1978) under which the use of instructional objectives might be ineffective. Furthermore, by providing pupils with objectives, the are in effect being given guidance as to what to expect for the objectivereferenced posttest.

An interesting aspect concerning the performance of the groups was revealed, namely, the treatment class of Group Y, which had the lowest Tscore at the Primary School Leaving Examination amongst all the six classes in the study, achieved the highest man score on the posttest (Table $5)$. 
Table 5: Mean and F values of treatment and control class by group with the objective-referenced posttest as the independent variable.

\begin{tabular}{lrrrrr} 
& N & Pre Mean & Mean & MS & Adj Mean \\
\hline \multicolumn{1}{l}{ Treatment Group } & & & & \\
\hline X & 40 & 14.93 & 27.85 & 7.67 & 27.00 \\
Y & 40 & 6.08 & 32.95 & 6.03 & 36.60 \\
Z & 40 & 17.83 & 37.18 & 4.13 & 34.80
\end{tabular}

\begin{tabular}{lrrrrr}
\hline \multicolumn{7}{l}{ Control Group } \\
\hline \multicolumn{7}{c}{} \\
$\mathrm{X}$ & 40 & 15.22 & 30.58 & 5.17 & 29.60 \\
$\mathrm{Y}$ & 40 & 7.05 & 25.85 & 6.29 & 29.00 \\
$\mathrm{Z}$ & 40 & 18.18 & 30.85 & 5.62 & 28.32 \\
\hline \multicolumn{7}{c}{} \\
\hline \multicolumn{7}{c}{ F (ANCOVA) } & P value & & \\
\hline $\mathrm{X}$ & 4.04 & 0.0481 & & \\
$\mathrm{Y}$ & 33.06 & 0.0001 & & & \\
$\mathrm{Z}$ & 48.99 & 0.0001 & & & \\
\hline
\end{tabular}

Note: Group X $\mathrm{p}<.05$ favouring the control instead of the treatment class.

By inference it may possible be that the pupils of the lowest ability benefited most from the provision of instructional objectives as an aid to learning the topics. though this finding does not confirm the view put forth by Hartley and Davies (1976) who suggested that mainly middle ability students benefit from the use of instructional objectives, empirical evidence does exist to counter this claim and to support this finding. Studies by Doth (1968), Wingard (1976) and Hunter (1982) similarly reported that lower ability students, when provided with instructional objectives, performed significantly better on the posttest with scores surpassing the middle ability groups in one case (Doty, 1968). 


\section{Conclusion and implications}

The main conclusion drawn from this study is that the use of instructional objectives as an instructional strategy does seem to enhance learning for less able secondary school pupils. another conclusion is, that, when presented with instructional objectives as an aid to learning, boys appear to benefit more than girls.

Some opponents however, argue that instructional objectives confine students' learning to specified objectives. Such outcomes are possible using objectives; they are just as possible without objectives. this study was interested only in the less able Normal-Course pupils, and for such pupils it can be argued that the task of learning will be made that much easier if what is to be learnt is pointed out to them rather than leave them to sort out and sieve for themselves what is relevant and necessary for evaluation - a process which they, being less capable, may not be able to handle. This study has churned up a point of significance - that the weakest pupils seemed to have benefited most from the instructional objectives. These less able pupils may have regarded the objectives provided to them as the guidance which could help them perform better in an assessment.

From the results obtained in this study, a question we might consider could be: It is really worth the extra effort needed to write instructional objectives for pupils and apply them? To answer this question is has to be borne in mind that this study is the only one on this nature in the educational milieu in Singapore. It is not incorrect to say that achievement of knowledge is a central goal of geography classes and this study has shown that achievement of knowledge can be improved through the use of instructional objectives. The issue however need not be just a matter of finding a simple, universal answer as to whether instructional objectives could be treated as one of several tools available to teachers. Keeping in view Melton's (1978) comments that "it is clear that a variety of complex conditions determine whether or not behavioural objectives enhance relevant learning..." individual teachers or schools would them be responsible for determining whether providing pupils with specific instructional objectives is worth the extra effort as this would depend on whether or not the objectives are likely to be useful in their own particular situation. Empirical research however has shown that objectives sometimes help but are almost never harmful (Duchastel and Merrill, 1973) 


\section{References}

Ascencio, C. E. (1984). Effects of behavioural objectives on student achievement: A meta-analysis of findings. Unpublished doctoral dissertation, Florida State University.

Bryant, N. Jr. (1970). The effects of performance objectives on the achievement of selected eighth grade science pupils in four predominantly black inner city schools. (Doctoral dissertation, Indiana University, 1970.) Dissertation Abstracts International, 31, 457.

Campbell, D. T. and Stanley, J. C. (1963). Experimental and quasiexperimental designs for research. Chicago: Rand McNally.

Doty, C. R. (1968). The effect of practice and prior knowledge of educational objective on performance. (Unpublished doctoral dissertation, Ohio State University, Columbus, 1968). Dissertation Abstracts International, 29, 3035A.

Duchastel, P. C. and Merrill, P. F. (1973). The effects of behavioural objectives on learning: A review of empirical studies. Review of Educational Research, 43, 53-69.

Hartley, J. and Davies, I. K. (1976). Preinstructional strategies: The role of pretests, behavioural objectives, overviews and advance organisers. Review of Educational Research, 46, 239-265.

Hunter, W. G. (1982). The effect of student knowledge of written instructional objectives on the teaching-learning process in selected eleventh grade American history classes. Unpublished doctoral dissertation, Southern Illinois University at Edwardsville.

Khoynejad, G. (1980). The effects of behavioural objectives, pre-questions, and a combination of both on intentional and incidental learning from written text by secondary school students. (Doctoral dissertation, The University of Texas at Austin, 1980.) Dissertation Abstracts International, 41, 2913A.

Lapolla, L. L. Jr. (1983). The effects of instructional objectives on achievement of knowledge of seventh grade social studies classes. (Doctoral dissertation, Indiana University, 1983.) Dissertation Abstracts International, 45, 2744A.

Melton, R. F. (1978). Resolution of conflicting claims concerning the effect of behavioural objectives of student learning. Review of Educational Research, 48, 291-302.

Smith, S. A. (1967). The effects of two variables on the achievement of slow learners on a unit in mathematics. Unpublished Master's Thesis, University of Maryland, College Park.

Stalians, K. L. (1978). The effects of advance organisers and behavioural objectives by reading level using an individualised remediation program on achievement of inner-city high school students. (Doctoral dissertation, University of Southern California, 1978). Dissertation Abstracts International, 39, 2889A. 
Wingard, H. E. (1976). The effects of presenting and discussing stated behavioural objectives on learning in a ninth grade unit on sex education, (Doctoral Dissertation, South Illinois University, 1976.) Dissertation Abstracts International, 37, 5621A.

Please cite as: Teo Boon Guat and Teh, G. P. L. (1987). The effectiveness of using instructional objectives with less able secondary school pupils. Australian Journal of Educational Technology, 3(2), 135-144.

http: / / www.ascilite.org.au/ajet/ajet3/teo.html 